\title{
Operational and investigative activities in places of imprisonment: new realities
}

\section{Оперативно-розшукова діяльність у місцях позбавлення волі: нові реалії}

Received: April 5, 2021
Accepted: May 7, 2021

Written by:

Serhii Yehorov ${ }^{74}$

https://orcid.org/0000-0003-4118-8284

Taras Shchurat ${ }^{75}$

https://orcid.org/0000-0001-8105-8324

Yevgen Polyakov ${ }^{76}$

https://orcid.org/0000-0002-6719-5450

Dmytro Tsekhan 77

https://orcid.org/0000-0001-6503-6985

\begin{abstract}
One of the factors influencing the effectiveness of sustainable development of the society is the state of the organization of the fight against crime, which is an integral part of any community. The success of the models of influence on crime chosen by the state depends on: the structure and dynamics of criminal activity in society; the intensity of the processes of self-reproduction of crime; the extent of public involvement in illegal social practices; the impact of criminal structures on economic, and political processes. The purpose of the work is to analyze the nature and structure of operational and investigative activities in places of imprisonment. The research methodology: dialectical method; method of analysis; formallogical methods; synthesis method; systemstructural method; methods of induction and deduction; statistical methods; and method of scientific abstraction. As a result of the study, the authors of the article came to the conclusion that operational and investigative activities in places of imprisonment are specific activities that differ significantly from other areas of operational and investigative activities, and require serious theoretical consideration.
\end{abstract}

\begin{abstract}
Анотація
Одним із чинників, які впливають на ефективність перманентного розвитку суспільства $€$ стан організації протидії злочинності, яка $є$ невід'ємною складовою будьякої спільноти. Від ефективності обраних державою моделей впливу на злочинність залежить: структура та динаміка кримінальної активності у суспільстві; інтенсивність процесів самовідтворення злочинності; масштаби втягнення населення у протиправні соціальні практики; вплив кримінальних структур на економічні та політичні процеси. Метою роботи $\epsilon$ здійснення аналізу сутності та структури оперативно-розшукової діяльності у місцях позбавлення волі. Об'єктом дослідження є оперативно-розшукова діяльності у місцях позбавлення волі. Предметом дослідження $\epsilon$ суспільні відносини, що виникають в процесі оперативно-розшукової діяльності у місцях позбавлення волі. Методологію дослідження становлять діалектичний метод; метод аналізу; формально-логічні методи; метод синтезу; системно-структурний метод; методи індукції та дедукції; статистичні методи; та метод наукової абстракції. У результаті проведеного дослідження автори статті дійшли висновку, що оперативнорозшукова діяльності у місцях позбавлення волі $\epsilon$ специфічною діяльністю, яка істотно відрізняється від інших напрямків оперативно-
\end{abstract}

\footnotetext{
74 Ph.D., Head of the Department of operative investigative activity of Odessa State University of Internal Affairs, Ukraine.

${ }^{75}$ Ph.D., Associate Professor of the Department of operative investigative activity of Odessa State University of Internal Affairs, Ukraine.

${ }^{76}$ Ph.D., Associate Professor of the Department of operative investigative activity of Odessa State University of Internal Affairs, Ukraine.

${ }^{77}$ Ph.D., Associate Professor of Department of Criminology and Criminal Enforcement Law of National University «Odesa Law Academy», Ukraine.
} 
Keywords: criminal punishment, operational and investigative activities, places of imprisonment, operative subdivisions, penitentiary institutions.

\section{Introduction}

In the current conditions of the development of public relations and the complex criminogenic situation in Ukraine, the system of execution of punishments has undergone significant changes. The changes, that are taking place, require a systematic understanding of the nature and structure of operational and investigative activities in places of imprisonment. розшукової діяльності, і потребує серйозного теоретичного осмислення.

Ключові слова: кримінальне покарання, оперативно-розшукова діяльність, місця позбавлення волі, оперативні підрозділи, установи виконання покарань.

In general, Ukraine is one of the leading places in the world in terms of imprisonment. Thus, the number of prisoners in Ukraine per 100,000 population is 410 . According to these indicators, our country yields only to the United States (710), Belarus (505), Kazakhstan (475), and Kyrgyzstan (420) (Figure 1) (Romaniuk, Vyshnevskyi \& Musyka, 2019).

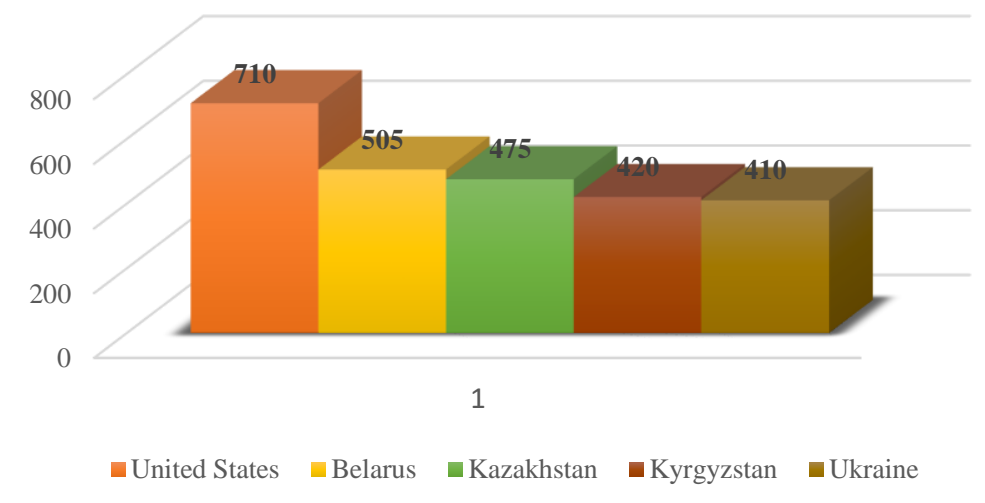

Figure 1. The number of prisoners per 100,000 population. Data provided by The European Union Advisory Mission (2019).

Analysis of penitentiary crimes in prisons showed that the most common crimes is escape from correctional facilities - $11.5 \%$; drug-related crimes - $3.4 \%$; threats or violence - 2.7 ; intentional severe or moderate damage - $2.3 \%$; premeditated murder - $0.8 \%$ (Figure 2) (Romaniuk, Vyshnevskyi, \& Musyka, 2019).

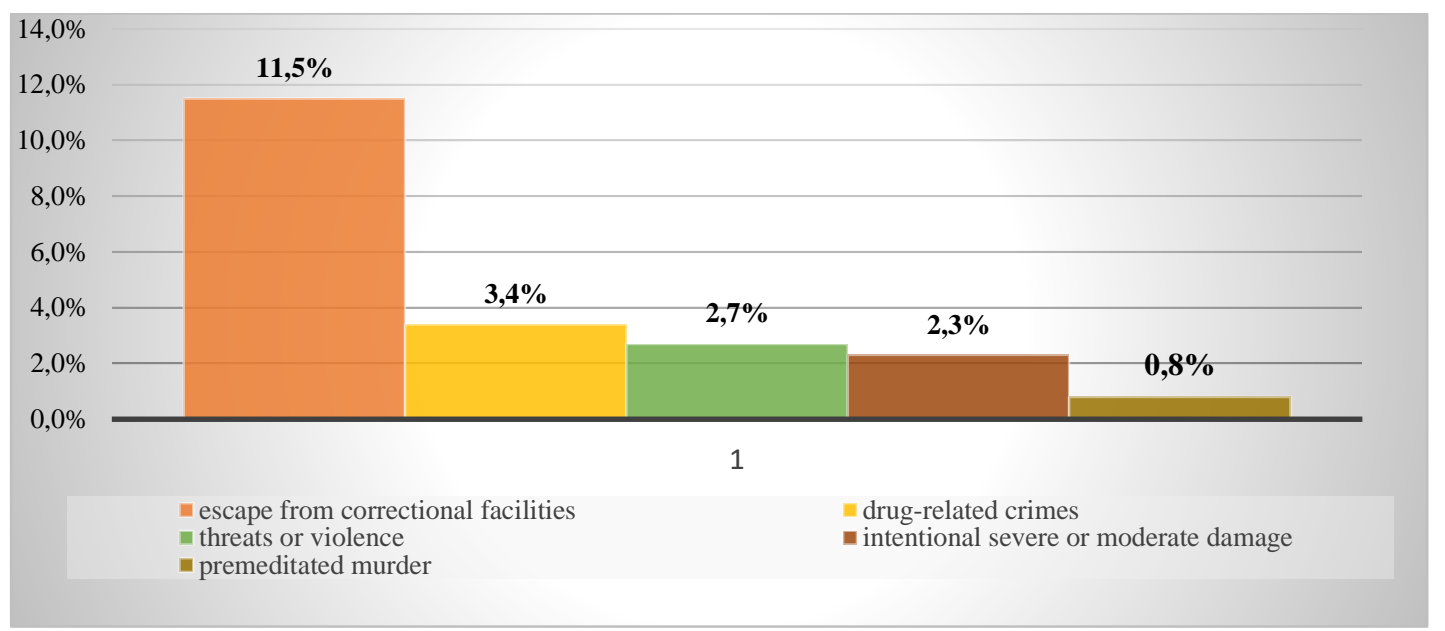

Figure 2. The most common crimes of penitentiary crimes in prisons. Data provided by The European Union Advisory Mission (2019). 


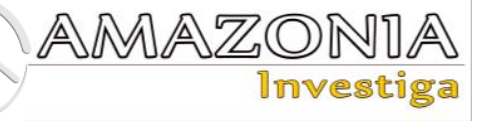

Such statistics indicate the importance of studying the nature and structure of operational and investigative activities in places of imprisonment and the need for operational and investigative activities against persons in prisons, taking into account socio-psychological factors that affect the identity of the offender, frustration, fear, alcoholism, drug addiction, homosexuality, interpersonal and intergroup conflicts, which lead to a change in the psychological state of the convict, as well as contributes to the commission of crimes by prisoners. Therefore, the effectiveness of the state's criminal policy is one of the principal indicators of Ukraine's wellbeing and potential.

Because of the above, it is essential to analyze the nature and structure of operational and investigative activities in places of imprisonment, to clarify the problematic issues of operational and investigative activities in such places, and to suggest ways to solve them.

\section{Theoretical Framework or Literature Review}

The essence and structure of operational and investigative activities in places of imprisonment were investigated by the following scholars: Alekseev, Ovchinsky, \& Pobegailo (2006), Bachinin (2005), Bogdanov (1983), Borodin (1990), Vinogradova (2019), Lyovochkin (2002), Marchuk (2013), Yatsishin (2008), Dryomin (2010), Kleimenov and Korneev (2012), Kozachenko (1991), Litvak (2002), Kudryavtsev, \& Eminov (2009), Dzhudzha and Vasilevich (2016), Dolgova (2010), Podobnyi (2012), Voitovich (2005), Gorbachevsky, Zakharov, \& Jerusalem (2001), Stashchak (2016ab), Nimchik (2005), Shinkarenko (2001; 2014), Romaniuk, Vyshnevskyi, \& Musyka (2019), Pavlenko (2016), Kalinovsky, \& Remsky (2011), Goryainov, Ovchinsky, \& Sinilov (2001), Tishchenko (2007), Khalilev (2012), Shumilov (2008), Koval (2019), and Vozniuk (2020).

Thus, Litvak (2002) notes that between the state and crime there are ambiguous relations. State power is historically doomed to take care of law and order, that is, to curb the growth of crime, without which the state perishes.

Analyzing the situation in Ukraine, Professor Dryomin (2010) notes that the institutional crisis due to the criminalization of society has affected not only the economic sphere but also the system of government and administration, as well as the judiciary and law enforcement agencies. The criminalization of society and the institutional crisis have manifested themselves as mutually determining processes.

In this context, Kleimenov and Korneev (2012) draws attention to the need to develop new and improve existing strategies and models of state influence on certain forms of crime, including in places of imprisonment. The importance of this issue is further determined by the fact that the existing scale of crime in prisons, as well as its essential characteristics, have negative consequences for society as a whole, in particular:

- reduce the effectiveness of achieving the main goal of criminal punishment correction and re-socialization of convicts;

- ensure the process of self-reproduction of crime through the mechanisms of influence of the criminal subculture, ensuring in places of imprisonment compliance with the rules of informal behavior and involvement in the systematic criminal activity of convicts after serving a criminal sentence. According to scholars, it can be considered a reliable sociological fact that the antipodes of culture (counterculture, which undoubtedly includes the criminal subculture) most actively (exponentially) develop in critical periods - during fractures, upheavals, revolutions. The foundations of leadership, which emerge in any closed environment, are intensively developed and can be formally expressed in the appropriate system of rules during such periods. In other words, of fundamental importance for the dynamics of the criminal subculture is the essence of the social situation, which can both stimulate and neutralize the criminogenic potential of the criminal environment;

- ensure the formation and development of criminal careers of persons with a high level of criminal influence, who further coordinate criminal activities in the relevant regions, including serving criminal sentences in prisons;

However, it should be noted that in the framework of the presented study, it is not intended to determine the essence of each of the above terminological constructions, as well as to determine their relationship between them. Moreover, as researchers rightly point out, the terminological discussion about the demarcation of these concepts that define the same phenomenon is impractical because it has no theoretical and practical meaning, it is farfetched, deepens the conceptual confusion, forces scientists to "switch" from the analysis of 
the content of the phenomenon to its etymological shell (Dzhudzha, \& Vasilevich, 2016).

For the sake of objectivity of the analysis it is necessary to state the position of other scholars, in particular, Dolgova (2010), who notes that the streamlining of the conceptual apparatus, theoretical provisions are part of the concept of combating crime, has not only scientific but also important practical significance.

We emphasize that we do not deny the need to study the conceptual and categorical apparatus, at the same time, we believe that the latter should be carried out within the framework of independent complex interdisciplinary research. At the same time, the analysis of scientific works on the substantiation of different theories of operational and investigative activities demands to pay attention to the essence of separate conceptual approaches of researchers, in particular, on the definition of "fight against crime" as optimum form of influence on crime by state institutions (Podobnyi, 2012).

The fight against crime consists of the following elements:

1) crime prevention;

2) their disclosure;

3) investigation of criminal cases;

4) court proceedings;

5) re-education and correction of convicts, and;

6) supervision of those released from prisons, carrying out special educational work with them.

Describing the criminological features of government relations with organized crime, other scholars also use the term "struggle", which in their opinion can, under appropriate conditions, acquire the characteristics of a special "dialogue", with elements of interaction, interpenetration, rapprochement, and even merging, and in many cases cooperation through corruption (Bachinin, 2005).

According to criminologists, the fight against crime means active, offensive activity by influencing the processes of determination, which determine the definition of the antisocial phenomenon and the application to persons who violate the criminal law of appropriate measures of state coercion (Alekseev, Ovchinsky, \& Pobegailo, 2006).

Borodin (1990) believes that the fight against crime in a broad sense means the policy, activities of public authorities, law enforcement agencies, NGOs, intergovernmental associations, and other structures to detect, detect, investigate and prevent crime.

Shumilov (2008) notes that scientists have worked hard to ensure that the priority goal of the state is to combat crime and not other forms of protection of man and society from criminal encroachment, ensuring their criminal security.

This targeted guideline for war (because the struggle involves the destruction of the enemy) with crime, which has remained in the law enforcement system, contains the potential danger of returning to the already passed path of punitive criminal policy, which is inherent in a totalitarian society. The fight against crime could not be declared the goal of justice. In fact, the most convenient and successful fight could be if criminals were physically exterminated. But the state is not at war with the sick and uneducated.

In the second case, the operational and investigative counteraction to crime in places of imprisonment must be analyzed through the prism of the activity approach, which presupposes the need to turn to the works of criminologists. As Professor Tishchenko (2007) noted, the definition of the activity approach in criminology is associated with its varieties, outlining mainly a particular direction, a particular plane of understanding of the object under study, which, on the one hand, is criminal activity, and on the other - crime investigation. The dual object of cognition is conditioned by the presence of two opposing systems, which, at the same time, are in direct connection. Thus, the practice of criminal investigation requires sufficient scientific support, which is due to the need to study the patterns of criminal activity. Thus, the theory of forensic science develops methodological approaches to the study of not only investigative activities but also criminal activities. Significant effectiveness in forensic research has been confirmed by systemic, functional, and operational approaches. Each of them, exploring different aspects of the object of knowledge, aims to achieve their goals. These areas are since the objects of study are inherently certain activities, with an internal structure and a certain direction, are characterized as systemic formations and have specific functions of the opposite direction - the struggle and counteraction.

Analyzing the direct structure of operational and investigative counteraction to crime in places of imprisonment of the priority, it is necessary to 


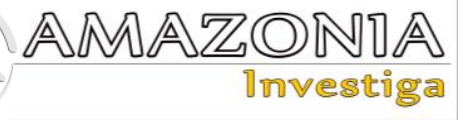

single out its implementation in such an organizational and tactical form as the identification of persons and facts of operational interest (Nimchik, 2005; Shinkarenko, 2001). As noted by Professor Podobnyi (2012), measures to identify persons and facts of operational interest constitute a single search complex throughout the operational service of the operational unit, an alarm system that operates continuously and independently of a specific crime or person but provides a timely signal of a crime, or the appearance of an object of operational attention. Areas of operational search are defined: among the population; in places of concentration of persons of operational interest, sale of stolen property; in criminogenic groups; among persons who are prosecuted or are serving a criminal sentence.

Further, Kozachenko (1991) defined operational and investigative prevention as the system of operative control and preventive influence concerning persons conceiving or preparing a crime, criminogenic situation (situation) and other antisocial phenomena, prevention of planned and prepared crimes with use, as a rule, operational and investigative forces, means, and methods. Thus, Kozachenko changed the emphasis on the goals and objectives of operational and preventive prevention of persons who plan or prepare a crime.

Analytical elaboration of scientific researches of the last years executed within the limits of the theory of operational and investigative activity testifies that, now, researchers use the term "counteraction" as a more coherent terminological construction with which we completely agree and use a terminological construction "operational and investigative counteraction of crime in places of deprivation will" to denote the appropriate comprehensive model of the influence of state-authorized law enforcement agencies on penitentiary crime.

However, even though operational and investigative activities have been studied by various scientists, the essence and structure of operational and investigative activities in places of imprisonment have not been sufficiently studied. This circumstance necessitates a comprehensive study of the stated topics.

\section{Methodology}

During the study of the nature and structure of operational and investigative activities in places of imprisonment used general and special scientific methods that provide an objective analysis of the subject, namely: dialectical method of scientific knowledge of socio-legal phenomena in their contradictions, development, and change; method of analysis; formal-logical methods; synthesis method; system-structural method; methods of induction and deduction; statistical methods; method of scientific abstraction; and some sociological methods.

Thus, the dialectical method of scientific knowledge of social and legal phenomena in their contradictions, development, and changes allowed us to objectively assess the current state of investigation of crimes committed by convicts in prisons in Ukraine.

With the help of the method of analysis, the state of scientific research was established in the problems of scientific and theoretical substantiation related to the investigation of crimes committed by convicts in places of imprisonment. Given the analytical information, relatively new approaches to the study of the research topic were developed and proposed.

Moreover, formal-logical methods allowed to clarify the content of key concepts and definitions used in the study, as well as to formulate the author's approaches to these issues and provide the author's definitions of some of the concepts.

Additionally, the method of synthesis made it possible to derive the features of the general principles of pre-trial investigation and modern criminal procedure policy of Ukraine in places of punishment.

What is more, the system-structural method allowed to find out the content and features of investigative and covert investigative actions in places of imprisonment. Thus, this method made it possible to understand that the conduct of operational and investigative activities in places of imprisonment has significant differences related to the legal status and regime in such institutions.

Using the methods of induction and deduction, the content of counteraction to the investigation of crimes committed by convicts in places of imprisonment is determined, as well as the state of coordination and interaction of the prosecution in general in criminal proceedings in which pretrial investigation is carried out on crimes committed by convicts in prisons.

Statistical methods were used in the study of empirical data and statistical material to obtain a 
mathematical basis for processing the results of the survey of general conclusions and conclusions to this study.

\section{Results and Discussion}

Analyzing operational and investigative counteraction to crime in places of imprisonment, it is necessary to highlight its specific features:

- first, the territory of the search work of a particular operational unit is limited by the perimeter of a special institution of execution of criminal punishment;

- secondly, the search work is carried out among the special contingent, which is differently aware of the forms and methods of covert operation of operational units;

- thirdly, regime measures are an additional tool of search work in terms of identifying material traces of criminal activity, tools, and means of committing crimes;

- fourth, the search work is carried out in a relatively constant environment of prisoners, which allows forming extremely stable operational positions;

- fifth, a narrow list of priority objects of search work:

a) material objects (weapons, drugs, objects adapted for use as weapons, etc.);

b) persons (criminally active convicts who have not taken the path of correction);

c) sixth, the objects of search work in places of imprisonment are certain elements of the infrastructure of penitentiary crime (facts of informal relations between the staff of the penitentiary institution and convicts, etc.).

Operational and investigative counteraction to crime in places of imprisonment can be considered in two formats - theoretical and praxeological.

In the first case, operational and investigative counteraction to crime in places of imprisonment can be defined as an appropriate theoretical model within which the optimal forms of influence on penitentiary crime at a specific stage of the historical development of society, legal system, and state are substantiated.

It should be noted that this theoretical model is characterized by the corresponding features:

- dynamism - is in permanent development, the results of which affect the level of penitentiary crime with a positive or negative result. Thus, the study of the practice of the penitentiary system shows that constant attempts to justify within this model, based on the experience of penitentiary systems of other countries, the concept of humanization of the penitentiary system, negatively affect the structure and dynamics of penitentiary crime, including institutional and psychological introduction and maintenance of such changes by the domestic penitentiary system, which leads to penitentiary conflicts between convicts and the administration of penitentiary institutions, which are resolved in particular at the level of the European Court of Human Rights. For example, the judgment of the European Court of Human Rights found that the court was particularly acutely aware of the fact that the applicant, together with other convicts, had been locked up twentyfour hours a day in cells with a very limited living space (the windows of the cells were closed in such a way that natural light did not come in, there was no opportunity to walk and that there was almost no opportunity to engage in any activity or have contact with other people). As a result, the court noted that the applicant's detention in such unacceptable conditions had constituted degrading treatment contrary to Article 3 of the Convention for the Protection of Human Rights and Fundamental Freedoms (United Nations, 1950). In the applicant's case, the situation was complicated as he was kept in a cell without a water tap and a washbasin, but only with a small pipe in the wall next to the toilet when water was supplied from the hallway. In considering the applicant's substantial conditions of detention, the court also noted that Ukraine had serious socioeconomic problems and that the pre-trial detention center administration was operating in challenging economic conditions and implementing new national legislation and relevant instructions. However, the court noted that the lack of funds could not, in principle, justify conditions that were so bad that they exceeded the threshold of conduct contrary to Art. 3 of Convention for the Protection of Human Rights and Fundamental Freedoms (United Nations, 1950). In addition, Ukraine's economic problems cannot, in any case, explain and justify certain conditions of detention that have been declared inadmissible in this case (European Court of Human Rights, 2014).

- adaptability - the specified theoretical model with the appropriate level of intensity 


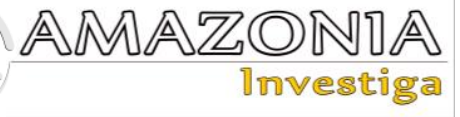

adapts to external and internal factors and, accordingly, changes the vector of its development. Thus, Ukraine's desire for European integration as a relevant factor has led to the rapid adaptation of such a model to the relevant content vector of development, which is traced in the results of scientific research (Vinogradova, 2019; Lyovochkin, 2002; Marchuk, 2013; Yatsishin, 2008).

- specific purpose - optimization of the applied level of activity of state institutions in combating penitentiary crime.

- $\quad$ isomorphism - a high degree of similarity or correspondence between the structure and content of the objects of the system, because, for example, the results of scientific research, in particular on optimizing the structural and functional support of the operational and criminal response to crime in prisons is always bodies and institutions of execution of criminal punishments and system of subjects of operational and investigative activity.

In addition, for the operational and investigative counteraction to crime in places of imprisonment as a theoretical model is characterized by an appropriate system of functions, in particular:

diagnostic - timely diagnosis of the applied level of functioning of the system of operative-search counteraction to crime in places of imprisonment for:

a) assessment of the real state of the structure and crime in places of imprisonment and identification of factors that affect such indicators;

b) determining the effectiveness of the implementation of certain functions by relevant institutions that ensure the application of criminal penalties and crime prevention. Thus, based on the results of scientific research and generalization of practice materials, the inefficiency of the penitentiary inspection and the inconsistency of its functions with modern needs, including post-penitentiary control over convicts, as a result of which a probation service was established;

c) identification of legislative conflicts and non-functioning norms in the field of criminal, criminal-executive, and operativeinvestigative legislation, which reduce the efficiency of operative-investigative counteraction to crime in places of imprisonment and development of proposals for optimization of legal regulation of this activity.

- prognostic - determination of relevant vectors of penitentiary crime development taking into account specific social conditions and necessary changes in legal, structural-functional, and tactical support of crime prevention. For example, the adoption of several countries in the post-Soviet space (e.g. Georgia) legislation aimed at neutralizing the criminal activities of "thieves in law" was considered a condition that would complicate the operational situation in Ukraine and places of imprisonment, including the main directions necessary optimization of relevant norms and institutions in Ukraine (Pavlenko, 2016; Kvasha, 2015; Kalinovsky, \& Remsky, 2011);

- $\quad$ systematizing - integration into a theoretical model of the results of various fields of scientific knowledge and applied activities (e.g., sociological research), building appropriate relationships between such elements and bringing them into the appropriate system. Thus, these provisions can be demonstrated by the implementation of certain legislative initiatives:

a) the formation of research in the field of criminal law and criminology to combat the activities of "thieves in law";

b) the development of relevant draft laws and departments;

c) integration and development of such knowledge and initiatives within the theory of operative-search counteraction to crime in places of imprisonment, and;

d) formation of separate recommendations on optimization of applied level of counteraction to crime in places of imprisonment (legal regulation, structural and functional support, etc.).

Currently, criminologists also recognize the existence of such a specific form of activity as operational prevention. The specifics of operational and preventive prevention are:

1) operative-preventive supervision is carried out over the persons who are put on the preventive account in connection with a high degree of probability of their criminal behavior;

2) the success of individual prevention is ensured due to the operational awareness of the contingent of persons who may embark on the path of criminal activity, and the 
characteristics of each person who committed anti-social behavior or was adversely affected by anti-social and criminal elements;

3) the environment of local criminally active inhabitants is fixed;

4) specific categories of persons of operational interest, their connections, way of life, behavior, and past are studied to obtain timely grounds for the application of preventive measures (Goryainov, Ovchinsky, \& Sinilov, 2001; Isichenko, 2001).

In the structure of operational and investigative prevention, they distinguish several relatively independent elements:

1) study with the help of methods and means of the operational and investigative activities of the contingent of persons who are under operative-preventive supervision;

2) documenting the facts and circumstances, actions, and deeds of these persons, which ensures the success of individual preventive measures;

3) initiative implementation of search measures to identify signs of preparation of crimes, criminal intentions, or criminal activity of persons, who are under operational and preventive supervision (Kudryavtsev, \& Eminov, 2009).

The implementation of this organizational and tactical form directly corresponds to the current version of Article 104 of the Criminal Executive Code of Ukraine (Law No. 1129-IV, 2003), which in the structure of the purpose of operational and investigative activities determines the study of causes and conditions that contribute to crimes in the colonies. Moreover, it should be noted that the legislator formulated this rule of law ignored an independent structural unit of operational and investigative prevention - individual preventive influence on persons prone to crime, which, in our opinion, needs clarification in Article 104 of the Criminal Executive Code of Ukraine (Law No. 1129-IV, 2003).

The next structural element of operational and investigative counteraction to crime in places of imprisonment is the operative development of convicts and arrested persons. Operational development is a unique form of operational and investigative activities that allows concentrated use of the entire arsenal of tools and methods, capture all information useful for combating crime and conspire secretly carried out the process of detecting crimes and searching for perpetrators. With the help of operative development, it is possible to penetrate the secrets of criminals, to establish the facts and circumstances necessary for their detection, to obtain information, the generalization of which contributes to a more effective arrangement of covert apparatus and improvement of operational and tactical tactics.

In this context, we stand in solidarity with the position of Podobnyi (2012), which defines operational development as a comprehensive system of operational and investigative measures and covert investigative actions, carried out under conditions of impossibility to achieve its objectives in another way:

a) operational units within the established operational and investigative case against a person or group of persons who are reasonably suspected of preparing serious or particularly serious or particularly serious crimes, in order to prevent or stop them, in respect of suspects (accused) who are hiding from the investigation, court, serving a criminal sentence, to search for and detain, establish the whereabouts of a person disappeared;

b) investigators, prosecutors, on their behalf operational units, in criminal proceedings against a person or group of persons who are reasonably suspected of committing these crimes, as well as to ensure the safety of court and law enforcement officers, persons involved in criminal proceedings, members of their families and close relatives in order to create the necessary conditions for the proper administration of justice (Podobnyi, 2012).

Analyzing and summarizing the scientific approaches of scholars, we can say that the fight against crime covers three areas:

1. The general organization of the fight against crime - is the organic essence of organizational (accounting and registration), management (forecasting, planning, coordination, definition of strategy and tactics to combat crime), preventive (implementation of programs and plans, implementation of preventive measures), control (study practices, crime trends), etc. actions of various bodies and institutions that interact to achieve common socially significant results.

2. Law enforcement activity, which consists in the implementation of specially authorized by 


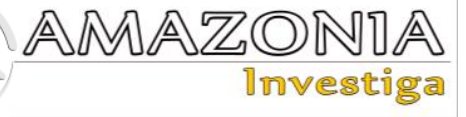

the state bodies (law enforcement agencies) measures provided by law to prevent the development of criminal intent in the previous stages of the crime, identify signs of crime, identify those who committed them, bring these people to justice, restore violated rights, freedoms and legitimate interests of people for damages from criminal acts.

3. Crime prevention is the implementation of economic, political, ideological, educational, legal, and other measures; it is an activity to identify and eliminate the causes and conditions of crime, certain types and groups of crimes, specific crimes, to prevent the completion of crimes at different stages of criminal behavior.

Of course, the above list of threats is not exhaustive. In the context of the above, it should be noted that changes in national legislation are not very dynamic, as required by modern life, but assistance to children who have been victims of sexual violence should be provided today.

\section{Conclusions}

As a result of the study, the nature and structure of the operational and investigative activities in the places of detention was evidenced and the following conclusions were drawn:

1. The study of the materials of the practice of operational units of penitentiary bodies and institutions shows the difference in its internal content in terms of the system of operational and investigative measures, which form the appropriate organizational and tactical complexes within the operational development. Thus, the results of the study indicate that within the operational development, taking into account the peculiarities of the functioning of places of imprisonment, the following operational and investigative measures are not carried out:

a) operational installation;

b) covert operational inspection;

c) visual observation;

d) covert intrusion into a person's home or other property.

2. There are significant features in terms of providing operational development in places of imprisonment by undercover workers. Due to the specifics of the objects of operative attention in places of imprisonment, the significant efficiency is confirmed by certain types of operative development - intra-chamber development of detainees or arrested. The study of work practice shows that it can be conducted on the initiative of employees of operational units, or the initiative of the investigator within particular categories of criminal proceedings.

3. Initiative intra-chamber development in the conditions of places of imprisonment, as a rule, is carried out concerning separate categories of persons for the purpose of revealing the not established facts of their criminal activity. According to the researchers, the information available in the personal files of convicts can be widely used to identify a specific category of persons who may be of operational interest, whose criminal activities have not been fully exposed before conviction. These are, first of all, persons who: have been wanted for a long time and are hiding from the investigation and the court; committed a crime as part of a group but did not identify their accomplices; did not have a permanent residence permit before conviction; convictions for theft on a particularly large scale that concealed the abduction; committed a crime using firearms that were not seized; repeatedly convicted of committing homogeneous crimes; criminals touring; convicted of counterfeiting banknotes; sentenced to life imprisonment.

4. Operational development of persons serving a criminal sentence at the initiative of the investigator may be carried out to disclose unsolved crimes of previous years if there is sufficient evidence that the person serving a criminal sentence is involved in its commission, which has repeatedly been noted in scientific sources.

Operational and investigative counteraction to crime in prisons is a system of overt and covert operational and investigative, intelligence, and operational and regime measures carried out by operational units of criminal penitentiaries to timely detect, prevent and detect crimes convicts in places of imprisonment, the establishment of previously unknown episodes of their criminal activity, involvement in unsolved crimes of previous years, as well as neutralization of particular elements of the infrastructure of crime in penitentiary institutions.

Regarding further scientific research, it is necessary to pay attention to the peculiarities of operational and investigative activities in places of imprisonment and the problematic issues of 
such activities to implement effective measures of investigation.

\section{Bibliographic references}

Alekseev, A.I., Ovchinsky, V.S., \& Pobegailo, E.F. (2006). Russian criminal policy: overcoming the crisis. Moscow: Norma. Recovered from https://www.studmed.ru/alekseev-aiovchinskiy-vs-pobegaylo-ef-rossiyskayaugolovnaya-politika-preodolenie-

krizisa_05777f43de1.html

Bachinin, V.A. (2005). Political Science: Encyclopedic Dictionary. St. Petersburg: Publishing house of Mikhailov V.A.

Borodin, S.V. (1990). Fighting crime: a theoretical model of an integrated program. Moscow: Science.

Dolgova, A.I. (2010). Criminology. Moscow: Norma.

Dryomin, V.M. (2010). Institutional crime theory and criminalization of society (doctoral thesis). National University Odesa Law Academy, Odesa. Recovered from http://dspace.onua.edu.ua/handle/11300/1410 Dzhudzha, O.M., \& Vasilevich, V.V. (2016). Criminology. Bulletin of the Criminal Law Association of Ukraine, 1(6),471-473. Recovered from http://vakp.nlu.edu.ua/article/view/173526

European Court of Human Rights. (2014). Vitkovskiy v. Ukraine. Application no. 24938/06. Recovered from https://hudoc.echr.coe.int/fre\#\{\%22itemid\%22:[ \%22001-126454\%22]\}.

Gorbachevsky, V.Y., Zakharov, V.I., \& Jerusalem, I.O. (2001). Forensic support for the detection and investigation of unsolved crimes of previous years (premeditated murders and grievous bodily harm). Kyiv: National Academy of Internal Affairs of Ukraine.

Goryainov, K. K., Ovchinsky, V. S., \& Sinilov, G. K. (2001). The theory of operational-search activity. Moscow: Norma.

Isichenko, A.P. (2001). Operational-search criminology. Moscow: INFRA-M.

Kalinovsky, O.V., \& Remsky, V.V. (2011). The Influence of "Thieves in Law" on the Criminogenic Situation in Ukraine. Fighting Organized Crime and Corruption (Theory and Practice), 24, 46-51 Recovered from http://nbuv.gov.ua/UJRN/boz_2011_24_6

Khalilev, R.A. (2012). Forms of operative-search activity and problems of their classification. Scientific Bulletin of Dnipropetrovsk State University of Internal Affairs, 4, 555-561 Recovered from http://nbuv.gov.ua/UJRN/Nvdduvs_2012_4_82
Kleimenov, M.P., \& Korneev, D.V. (2012). Crime leaders yesterday and today. Omsk University Bulletin, 3, 404-414.Recovered from https://in.booksc.org/book/36417355/71dfa7

Koval, T. (2019). International legal acts regulating the work of convicts. Bulletin of Karazin Kharkiv National University, 26, 171-175. Recovered from https://periodicals.karazin.ua/law/article/view/1 2705

Kozachenko, I. P. (1991). Operative-search prevention. Kaliningrad Higher School of the Ministry of Internal Affairs of the USSR. Kaliningrad.

Kudryavtsev, V. N., \& Eminov, V. E. (Eds.). (2009). Criminology. Moscow: Norma.

Kvasha, O.O. (2015). Problems of introducing the concept of "thief in law" into the Criminal Code of Ukraine. The rule of law state, 26, 366376.

Law No. 1129-IV, Criminal Enforcement Code of Ukraine. Bulletin of the Verkhovna Rada of Ukraine, Kyiv, Ukraine, July 11, 2003. Recovered from Recovered from http://zakon0.rada.gov.ua/laws/show/1129-15.

Litvak, O.M. (2002). State control over crime (criminological aspect). Kharkiv: Pravo.

Lyovochkin, V.A. (2002). Organizational principles of ensuring the implementation in Ukraine of international standards on the rights and freedoms of persons sentenced to imprisonment (doctoral thesis). National Academy of Internal Affairs, Kyiv. Recovered from https://i-rc.org.ua/index.php/na-dopomoguprakt-pracivn/71-liovochkin-v-a

Marchuk, A.I. (2013). Criminological principles of classification of convicts (doctoral thesis). National University Odesa Law Academy, Odesa. Recovered from http://hdl.handle.net/11300/2142

Nimchik, V.P. (2005). Organizational and tactical bases of operative search. Kyiv: Osnova. Pavlenko, S.O. (2016). Ways to improve the legal regulation of counteraction to persons classified as "thieves in law" in Ukraine. Scientific Bulletin of Kherson State University, 6(3), 73-79

Podobnyi, O.O. (2012). Operational and investigative activities of law enforcement agencies in the fight against mercenary and violent organized crime. Odessa: Odessa State University of Internal Affairs.

Romaniuk, O., Vyshnevskyi, O., \& Musyka, V. (Eds.). (2019). Operative-search activity and security in penitentiary institutions. Bila Tserkva: The European Union Advisory Mission. Recovered from https://irc.org.ua/files/posibnik-ORD-ta-bezpeka.pdf 


\section{AMAZONIA \\ Drvestiga}

Shinkarenko, I.R. (2001). Problems of operativeanalytical search of signs of organized crime. Bulletin of Lviv State University of Internal Affairs, 1, 57-65

Shinkarenko, I. (2014). Problems of formation of the modern normative base of operative-search activity according to the current Criminal procedural code. Scientific herald of the Dnepropetrovsk state university of internal affairs, 1, 226-238. Recovered from http://nbuv.gov.ua/UJRN/Nvdduvs_2014_1_32 Shumilov, A.Yu. (2008). Problems of legal regulation of operational-search activity: ten years later (constitutional, administrative, criminal, criminal procedural and criminal investigative aspects). Moscow: Publishing house Shumilova I.I.

Stashchak, M. (2016a). Modern signs of operative-search forms of counteraction to crime. Bulletin of Luhansk State University of Internal Affairs named after E.O. Didorenko, 2(74), 293$300 . \quad$ Recovered from https://journal.lduvs.lg.ua/index.php/journal/arti cle/view/539

Stashchak, M. (2016b). Differentiation of forms of operative-search activity. Bulletin of Luhansk State University of Internal Affairs named after E.O. Didorenko, 3(75), 125-133. removed from Recovered from https://journal.lduvs.lg.ua/index.php/journal/arti cle/view/492

Tishchenko, V.V. (2007). Theoretical and practical bases of crime investigation methodology. Odesa: Phoenix.

The European Union Advisory Mission. (2019). Operative-search activity and security in penitentiary institutions. Recovered from https://i-rc.org.ua/files/posibnik-ORD-tabezpeka.pdf

United Nations. (1950). Convention for the Protection of Human Rights and Fundamental Freedoms. Recovered from Recovered from https://www.echr.coe.int/documents/convention _eng.pdf

Vinogradova, S.O. (2019). Humanization of the system of execution of punishments in the conditions of European integration processes. (Degree of Candidate for Law) Oles Honchar Dnipro National University. Dnipro. Recovered from https://dduvs.in.ua/wpcontent/uploads/files/Structure/science/rada/d2/ dissertations/3/3.pdf

Voitovich, E.M. (2005). Theoretical and practical questions of the methods of investigation of murders of the past years (doctoral thesis). Zaporizhzhia National University, Zaporizhzhia. Recovered from https://www.dissercat.com/content/teoreticheski e-i-prakticheskie-voprosy-metodikirassledovaniya-ubiistv-proshlykh-let Vozniuk, A. (2020). Combating organized crime in Ukraine: prospects for improving criminal law. Bulletin of the Penitentiary Association of Ukraine, 1, 176-194. Recovered from https://doi.org/10.34015/2523-4552.2020.1.18 Yatsishin, M.M. (2008). Humanization of criminal executive law of Ukraine. Legal Ukraine, 9, 100-104. Recovered from https://evnuir.vnu.edu.ua/handle/123456789/206 9 